\title{
10 Attracting and retaining international students as skilled migrants
}

\author{
Lesleyanne Hawthorne, University of Melbourne
}

IN PRESS (mid-2017), Chapter 10 in High-Skilled Migration: Drivers, Dynamics and Policies, Ed. M Czaika, Oxford University Press, Oxford

\subsection{Introduction}

By 2014 one in seven people in the world were temporary or permanent migrants outside their country of origin, most with limited opportunity for safe or regular migration. In the coming decades, according to the International Organization for Migration (IOM), global migration will "transform in scale, reach and complexity, due to growing demographic disparities, the effects of environmental change, new political and economic dynamics, technological revolutions, and social networks" (Laczko, 2014). Skilled migrants are the most certain to be sought, at a time when unprecedented numbers of individuals seek mobile livelihoods, with careers less configured to national boundaries (Ruhs, 2003). The International Labour Organization and the World Health Organization affirm the individual's right to move, regardless of source country or sector need. The IOM highlights the benefits for the actors involved, while the United Nations calls on governments to develop mechanisms to facilitate the easy and rapid movement of workers. The European Migration Network urges greater worker mobility - not merely for Europeans but for third country nationals, through the development of bilateral and multilateral cooperation agreements designed to secure an economic triple win. ASEAN ministers have committed to moving ahead with "the liberalization of temporary migration of skilled manpower across national borders", while the Asian Development Bank (ADB) has described diasporas as "assets which can be mobilized" (IOM, 2003 ADB, 2006; Chia, 2011: 225; UN, 2013).

\subsection{Major skilled migration pathways}

\subsubsection{The policy context}

Within this context an unprecedented number of governments have developed skilled migration policies. According to Ruhs (2014), the role of the nation state is to decide "how to regulate the number, selection and rights of migrant workers admitted in order to achieve... four inter-related and sometimes competing policy goals": economic efficiency, distribution, national identity and social cohesion. A second key policy challenge exists. It concerns which skilled migration pathway/s to prioritise, at a time when options include:

- Permanent skilled migration, where migrants are selected by defined criteria on a sponsored or on an 'independent' basis;

- Temporary labour migration, where migrants are admitted by employers or states to fill specific positions, addressing labour market needs in undersupplied sectors or sites;

- Bilateral or multilateral agreements, where migrants secure entry and employment rights in host countries through treaties negotiated on a generic basis, then applied to all or specific occupational fields; and 
- The study-migration pathway, where international students are first admitted to study, then category-switch to remain in their host country.

A growing number of OECD governments have developed migration programmes designed to attract and retain skilled workers. They have expanded temporary entry options, targeting international students and sponsored workers. They have facilitated transition from temporary to extended or permanent resident status, combining supply and demand-driven strategies. They have designed regional settlement incentives to attract skilled migrants, supported by flexible entry requirements. Further, they have supported such measures by sustained and increasingly innovative global promotion strategies (Hawthorne, 2010).

\subsubsection{Evolution of the study-migration pathway}

Within this context international students have emerged as a prized and contested human capital resource, with extraordinary claims made for their workforce capacity. According to a Canadian analyst, former students are fluent transnationalists with potential to "increase the economic competitiveness and creativity" of host communities, while becoming "agents of development for an economy seeking greater participation in a more competitive global market, particularly... new technologies" (Belkhodja, 2011). A German report asserts international students to "possess skills which can considerably accelerate their social and economic integration", with the decision to study abroad a signal to employers "that they can establish themselves and thrive in foreign contexts" (Mayer et al., 2012). As early as 2002, Vertovec described the study-migration pathway as "an integral part of transnational migration systems", facilitating labour circulation through "the increasing incidence of programmes for recruitment with a specific view towards longer-term or permanent settlement" (Vertovec, 2002, 2004). International students in turn are demonstrably motivated to migrate - seeking countries where this represents a definite policy option. A 2012 British Council survey of 153,000 international students found while most sought "a high quality, internationally recognised education from highly reputable institutions... respected by potential employers", the opportunity to remain on course completion "massively impact(ed on) prospective student opinion and expectations" (MacGregor, 2012). Family collectives fund and support this process. Many engage in "the new economics of labour migration" by sponsoring one or more members to study abroad - maximising scope for migration, while mitigating the risks associated with this (Hagen-Zanker, 2008). Governments, agents and education providers facilitate entry. In 2005 the US and the UK were earning \$US14.5 billion and $£ 7.5$ billion annually from international students. Since the onset of the global financial crisis in 2008, the incentive to expand international student enrolments has grown. By 2010 export education had emerged as Australia's third top industry, in 2014 generating \$A18 billion per year compared to \$C8 billion for Canada.

In human capital terms, international students represent an elastic and rapidly growing resource - what might be termed an adjunct workforce in waiting. In 2002, 2.1 million were studying abroad, rising to 4.1 million at the tertiary level within 8 years (OECD, 2012). By 20257.2 million international students are predicted globally. In Australia, 66 per cent of Indian and 38 per cent of Chinese students categoryswitched to become permanent skilled migrants by 2005. In New Zealand, a study-to-work followed by a work-to-residence pathway has existed for more than a decade, retaining a third of all international students. In 2013, Canada launched a strategy designed to double the number of international enrolments within 10 years (to 450,000), after tripling retention. According to a recent OECD study (2014), Asian students increasingly seek migration, at a time when "1.6 million Asian nationals migrated to the OECD area, accounting for one third of all migrants", and an estimated 15-30 per cent remain in host countries (Table 10.1). 


\section{<Insert Table 10.1 here>}

While three-quarters of international students have enrolled to date in the US, Australia, UK and Japan, the range of host countries is rapidly expanding. The US dominates, with 974,926 international students enrolled by 2015 (principally derived from China, India and South Korea), compared to 482,252 in Australia and 436,585 in the UK (Institute of International Education, 2016; Australian Education International, 2016; UK Council for International Student Affairs, 2016). According to the latest crossnational OECD data China doubled its enrolments from 2005 to 2011 (to 292,600), to emerge as the third top international student destination. Extraordinary recent growth has also occurred in the Republic of Korea (from 15,500 to 62,700 students) and Spain (from 17,700 to 62,600), followed by Canada, Sweden, the Netherlands, Greece, Turkey and Malaysia (OECD, 2014), while Australian international student enrolments by 2017 had risen to 712,884 enrolments and 554,179 full-time incountry students (Knott, 2017).

\subsubsection{International students - a productivity premium?}

In terms of ethics, the recruitment of these international students may be less problematic than the OECD norm - selection of mature-age migrants trained by countries of origin. In theory they should also sidestep skills discounting (an endemic challenge to the effective transfer of human capital). According to Statistics Canada, for instance, "by the early 2000s, skilled class immigrants were actually more likely to enter low-income and to be in chronic low-income than their family class counterparts", with half of all chronically poor immigrants in the skilled economic category (Picot et al., 2007; Hawthorne, 2008). The problem was most acute for migrants trained in developing countries, nonnative speakers of English or French, and those qualified in regulated and/or over-supplied fields. A 2014 European report identified "persistent employment gaps between natives and foreign-born residents", including "protracted periods of inactivity, unemployment, or long tenures in low-skilled work" (Benton et al., 2014).

This challenge is worth illustrating in relation to health migration. Since 2010 Japan has admitted Filipino and Indonesian nurses through Economic Partnership Agreements designed to care for its "super-ageing" society. Following provision of three to four years of training in Japan, access to permanent residence is then contingent on their passing the national licensing exam. Outcomes to date from these agreements have been catastrophic. Just 2 per cent of Filipino and 1 per cent of Indonesian nurses passed the exam in 2010, compared to 90 per cent of Japanese nurses and 80 per cent of Chinese nurses (Shun, 2012). Comparable challenges exist in multiple OECD countries. International students, in marked contrast, have the potential to offer governments and employers what might be termed a productivity premium. They are far younger than mature migrants selected offshore (typically aged 24 years). They face no regulatory barriers, with careers likely to span decades. In Australia, for example, 99 per cent of former international medical students are employed within four months of course completion, compared to 57 per cent of medical migrants within five years of arrival. Full-time employment rates for students qualified in dentistry, pharmacy and nursing are 98 per cent, 96 per cent and 66 per cent respectively (compared to 40 per cent, 32 per cent and 66 per cent for offshore migrants in their first five years in Australia) (Hawthorne and To, 2014).

Despite the potential merits of international students as skilled migrants, constructing the studymigration pathway has proven complex however. According to Ruhs, economic theory provides three rationales for skilled migration programmes: namely, "To support labour expansion by complementing the skills base of the domestic workforce; to facilitate economic growth; and to provide fiscal benefits 
(while...) maximising overall gains (and) minimising adverse distributional effects for existing residents" (Ruhs, 2013). These are potentially competing goals which can lead to unintended policy consequences. Select tensions are explored below in relation to the UK, US and Australian studymigration pathways.

\subsection{The study-migration pathway - three case studies}

\subsubsection{UK - pressure to reduce net migration}

In 2004, at the time of the European Union Eastern Enlargement, the UK, Ireland and Sweden were the sole members to allow the A8 group unrestricted access to domestic labour markets. Their impact on net migration rates to the UK was soon profound. According to Salt and Millar (2006) "Opening up the labour market to citizens of the new member states of the European Union in May 2004 initiated what is almost certainly the largest single wave of in-migration (with Poles the largest ever single national group of entrants) that the British Isles have ever experienced". Simultaneously, the Home Office planned the launch of the "biggest change in migration policy of recent times, a points-based management strategy for economic migration, due to come into full operation from 2007". By 2005, 3.035 million foreigners were resident in the UK, including 1.5 million who were employed. Close to half were from Europe. The scale of 'third country' arrivals was also significant at this time, with the top five countries for work permits and first permissions India $(29,261)$, the US $(9,186)$, Australasia $(5,548)$, the Philippines $(4,650)$ and South Africa $(4,404)$.

In the year to June 2007, an additional 574,000 migrants arrived, at a time when 605,375 A8 country nationals were registered to work, far exceeding projections. According to a media analysis, "The Home Office reckoned Britain would attract 13,000 migrants a year from the new member states, including Poland. In fact, at least 700,000 have come since then" (Doughty, 2007; Home Office, 2007). Despite research demonstrating the Poles to be productive, well-educated, low-paid, and among the least welfare-dependent of immigrants ('high-quality migrants in low-skill jobs'), according to migration critics a "vast unplanned experiment" was underway. As net migration soared to 190,000, the tabloids defined the national fabric as imperiled (e.g. Green, 2007: 4).

The scale of international student arrivals fuelled this debate, at a time when 60 per cent of nonEuropean migration was for study purposes. From 2007 the UK government had facilitated international student retention through its five tier 'managed migration' system - defining criteria by which third country nationals could enter the UK and remain. Students could secure part-time work while enrolled (Tier 4). On graduation they were eligible to apply for permanent points-based selection through Tier 1 (as "highly-skilled individuals to contribute to growth and productivity"); or for temporary migration through Tier 2 (as "skilled workers with a job offer to fill gaps in the UK labour force", with scope for permanent resident status) (Hawthorne and To, 2014). This clarity was precisely what international students had sought. Demand for UK study visas surged, with India, Pakistan and China predominating. By 2009, 34,180 postgraduate applicants were approved for Tier 1 migration (compared to 16,171 in 2008). In 2012 an estimated 15 per cent of international students admitted in 2007 remained (GovUK, 2014). Their retention was increasingly challenged however as national debate fixated on net migration (Migration Advisory Council, 2012). Since 2008 the global financial crisis (GFC) has had a significant (though reducing) impact on UK domestic employment. While the government had minimal scope to curb A8 arrivals (short of exiting the EU), levers existed to reduce third country skilled migration. 
Although the government believed the public to generally support migration, it favoured this only when there was "a clear and evident need as well as a value proposition" (Simmons, 2014).

According to the Home Office, defining or predicting migration's impact on domestic labour markets is complex. The Office is required to "make an informed judgement based on existing evidence in order to provide robust advice". In its best estimate, while there had been minimal evidence of migrants displacing UK workers in buoyant economic times, this had changed with the onset of the GFC. Labour market substitution had occurred, with displacement "particularly linked to non-EU migration" (despite this risk being likely to dissipate over time, and being greater for low-skilled workers) (Devlin et al., 2014). The election of the Cameron government in 2010 led to immediate review of Labour's Highly Skilled Migration Programme, followed by rapid policy changes (Migration Observatory, 2014a). The rise of the UK anti-immigration Independent Party (UKIP) also fuelled public debate from this time. By 2011 2,081,000 EU citizens were resident in the UK, of whom 872,000 were A8 citizens (42 per cent) with 669,000 employed (Vargas-Silva, 2013; Migration Observatory, 2014b). Net migration had risen to 250,000 per year. Within this context Prime Minister Cameron "vowed to bring yearly net migration to under 100,000" (initially "tens of thousands"), with third country nationals most directly amenable to policy manipulation (AFP The Times, 2014; Somerville, 2015).

To achieve this, Tier 1 of the managed migration system was closed in 2010. A 20,700 annual limit was imposed on Tier 2 (which facilitated employer sponsorship of non-European workers). UK studymigration options were reviewed, with scenarios ranging from "complete closure" to preservation of "the status quo". (An unprecedented 30,000 policy submissions were lodged at the Home Office to protest this.) The Post-Study Work Route was shut in April 2012. While a modest rise in Tier 2 approvals was evident, this catered to all migrants with skills - by no means compensating former international students. The impact on student enrolment and retention became profound. In March 2014 the Home Office reported a drop of Post-Study applicant approvals from 23,149 to 713 (particularly affecting former Nigerian, Bangladeshi and Sri Lankan applicants). A mere 6,238 grants of extension were made to former international students - "a large fall from a comparable figure of 38,505 in 2012", reflecting the Tier 1 category closure (GovUK, 2014). From 2007 to 2013, the scale of high-skilled migration to the UK reduced from 125,000 managers or professionals to 97,000 . Net immigration fell to 176,000 (31 per cent lower than 2010 levels), with former students' share vastly reduced (Table 10.2). Despite this the 2013 British Social Attitudes survey found that 56 per cent of respondents wanted immigration "reduced a lot", while 77 per cent wanted it reduced a lot or a little (Blinder, 2015). By 2014 non-European migrants made up 45 per cent of the 632,000 total arrivals, compared to 42 per cent of EU nationals and 13 per cent returning British nationals (Blinder, 2016).

\section{<Insert Table 10.2 here>}

According to the UK Migration Observatory, "a crucial trade-off in migration policymaking" was occurring, with "restrictions on one source of immigration lead(ing to growth) in another path", favouring 'old EU' rather than third country or A8 nationals" (Migration Observatory, 2014a). In line with this, the UK suffered an unprecedented decline in international student applications (-29 per cent), mostly notably from India. In the view of the education sector, this policy represented economic madness at a time when the export education industry was generating $£ 17.5$ billion a year, with few sectors of the economy showing "the capacity to grow and generate export earnings as impressive(ly) as education" in the GFC (Travis, 2011; Higher Education Funding Council for England, 2014). According to a UK Universities report, international students had become casualties of "the tricky 
minefield of migration" regardless of merit - in a context where the government lacked information as to whether "opposition to immigration attached equally to all groups", and whether respondents to opinion polls were "thinking about foreign students, workers or asylum seekers" (Migration Observatory, 2011). Net inward migration of non-EU nationals plummeted "as the criteria for obtaining student, family and work visas were tightened with the aim of reducing non-EU net migration", followed by a degree of recovery in 2015 (House of Commons Library, 2016; Office of National Statistics, 2016).

In 2015 migration was predicted to become a key UK election issue, in a context where "the pledge on net migration has been an epic failure" (Somerville, 2015). Arrivals had remained stubbornly high - the Office of National Statistics revealing a gain of 2.53 million people from 2001-11 (Office of National Statistics, 2014). Net migration rose further to 336,000 in the year to March 2015, leading Prime Minister Cameron to confirm his previous pledge to dramatically reduce levels following the Conservatives' surprise majority win (House of Commons Library, 2016). By late June 2016 UK revolt against the scale of immigration was widely conceded to be the primary driver of the 'Brexit' Referendum vote, culminating in the UK's decision to exit from the EU following a period of toxic public debate in part fuelled by the UKIP party (Sakur 2016; Somerville 2016). The outcome resulted in immediate concern for the economic and global stature impacts on universities (Sharma, 2016).

The point to note is that remarkably little evaluation of the UK's study-migration pathway had occurred - including former international students' attractiveness to prospective UK employers. The highly regarded Migration Advisory Council has not undertaken a formal review or advocated the pathway's near closure. According to Salt there is in fact evidence UK corporations target international students as prospective employees to spearhead global expansion, based on "deliberate selection of particular types... according to their nationality or disciplinary training" (Salt, 2011). As the migration source most directly amenable to government control, however, international student flows seem certain to remain contracted. In line with this, a mid-2016 House of Commons Library report noted:

"Study was the most common reason for immigration during the period 2009-12, and the reduction in the number of people migrating to the UK to study since then reflects a reduction in the number of Tier 4 student visas issued to students from outside the EEA and Switzerland" (House of Commons Library, 2016: 14).

\subsubsection{US - workforce complementarity or substitution?}

In the five years prior to Trump's election, there was robust US debate on immigration reform, including the potential introduction of a skilled migration policy (see Chapter 7). A key dimension of this concerns the extent to which the US should prioritise the retention of international doctoral students. When "sweeping immigration legislation" was approved by the Senate Judiciary Committee in May 2013, a central proposal was refinement of H-IB temporary visas, to permit PhD holders qualified in the US or overseas to apply for green cards "without an offer of employment and subject to no numerical limit" (Sumption and Bergeron, 2013). In October 2014, as legislation lay stalled, the US Department of Homeland Security proposed new visa rules to "open doors to the world's brightest talent", including measures to prioritise the entry of "outstanding professors and researchers" of high prospective value. ("[I]mmigrants represent 50\% of PhDs working in maths and computer science and 57\% of PhDs working in engineering in America [and] ... 26\% of all US-based Nobel Laureates over the past 50 years were foreign-born" [Lee, 2014].)

As demonstrated by successive National Science Foundation reports, the US has a longstanding reliance on international doctoral students, with China and India the primary recent sources. In 201166 per cent 6 
of $\mathrm{PhD}$ graduates remained resident in the US for at least five years, most notably those from China ( 85 per cent), India (82 per cent) and Europe (62 per cent) (Finn, 2014). By 2014 886,052 international students were enrolled in the US (rising to 974,926 in 2015), principally in business and management (21 per cent), engineering (19 per cent), maths and computer science (10 per cent) courses. 329,854 were undertaking graduate degrees (compared to 311,204 in 2013), with substantial numbers enrolled in doctoral programmes. Minimal data existed however on the career patterns of US-trained foreignborn science and engineering workers, at a time when global competition for elite workers was intensifying.

A 2007 expert workshop identified disturbing trends in relation to this. International doctoral students' dramatically increased stay rates of the 1990s had "levelled off", at a time when graduate student recruitment was set to become a more "complex, costly and competitive domain", though "integral to the financial health" of many US institutions (Choudaha and Chang, 2012). From 1998 to 2008 the US share of the world's top 1 per cent of scientific papers fell from 62 per cent to 52 per cent, at a time when Confucian university systems increasingly exhibited a "special developmental dynamism", supported by "one chance" national examination systems and "accelerated public investment in research and 'world-class' universities" (Marginson, 2010). They are predicted to match the output of western universities in a generation, at a time when the US science and engineering (S\&E) workforce is ageing (a third aged 50 or more years), and Asian migrants already constitute a quarter of S\&E workers. The retention of Chinese and Indian students has significantly declined, with stay rates influenced by home country economies and repatriation incentives, such as China's mass hiring of western-trained PhDs to drive economic development (Freeman et al., 2008) (Table 10.3).

\section{<Insert Table 10.3 here>}

As the global financial crisis hit the US, a survey confirmed economic conditions to determine the "talent for citizenship (trade)", with former international students starting careers in countries "where they have more and better... opportunities, receive higher salaries" (Musumba et al., 2011). This constitutes a major strategic issue. According to the Science and Engineering Indicators 2016 report, the US has dropped to $11^{\text {th }}$ in terms of R\&D intensity among national economies tracked by UNESCO and the OECD (compared to $8^{\text {th }}$ in 2009), with Israel and South Korea tying for top rank, followed by Japan, Finland, Sweden, Denmark, Taiwan, Switzerland, Austria and Germany (National Science Board, 2016).

By 2012 concern was rising at the US's lack of "a clearly articulated pathway between higher education and immigration" relative to global competitors (Hordern, 2012). Critics charged the government with being insufficiently proactive - advocating the acceptance of far larger numbers, at a time when international students constituted just 4 per cent of US graduate enrolments (with far higher proportions in Australia and the UK). They asserted the study-migration pathway to require review, given permanent residence could take 16 years to secure from point of arrival. While the US allowed "an easy attestation procedure for employers seeking college-educated foreigners to fill jobs that require a college degree under the H-IB program", according to Martin and Ruhs (2010) opening the labour market to more guest workers remained "one of the roughest issues facing Congress", with no certainty former students would secure permanent resident status.

Within much of the literature, the labour market value of migrants, including those holding doctoral qualifications, is an assumed benefit. This bears examination however, as demonstrated by Borjas and select colleagues in a succession of studies (Borjas, 2009a, b; Borjas et al. 2011; Borjas and Doran, 2012). By 2000, 37 per cent of US doctorate degrees were awarded to foreign students (ranging from 
26 per cent in the life sciences to 51 per cent in engineering). Their retention in science and engineering in fact was found to have had a negative rather than a positive impact. Analysis of national survey data demonstrated that "a foreign student influx into a particular field at a particular time had a significant and adverse effect on the earnings of competing doctorates in that field who graduated at roughly the same time" - in science and engineering depressing wages by 3-4 per cent. "Supply shock" had led to the "increased prevalence of low-pay postdoctoral appointments in fields that have softer labor market conditions", and the flight of US scientists to "professional occupations that have not been targeted by immigration" (Borjas, 2009b; Borjas et al. 2011). Such negative wage impacts were nearly identical to those previously identified by Borjas (2009a) and Borjas et al. (2011) when comparing migrants to lessskilled US workers.

In 2012, following "explosive growth" in the measurement of migration's labour market impact after years of "flux and confusion" (Card, 2009), Borjas and Doran assessed the impact of Soviet mathematician migration to the US from 1992. They analysed "unique international data on the publications, citations, and affiliations of mathematicians" - their findings once again challenging brain-gain assumptions. In particular they found:

"[...] a negative productivity effect on those mathematicians whose research overlapped with that of the Soviets. We also document an increased mobility rate (to lower-quality institutions and out of active publishing) and a reduced likelihood of producing 'home run' papers. Although the total product of the pre-existing American mathematicians shrank, the Soviet contribution to American mathematics filled in the gap. However, there is no evidence that the Soviets greatly increased the size of the "mathematics pie"" (Borjas and Doran, 2012).

The National Science Foundation, the Chamber of Commerce and the US education sector advocate the retention of foreign doctoral students as elite skilled migrants, in a context where doctoral employment and wage levels have largely been recession-proof. The Migration Policy Institute asserts that "The most talented economic-stream immigrants may require separate treatment from the 'merely talented'... since attracting more of these workers is a priority for most governments" (Papademetriou and Sumption, 2013: 11-12, 15). Their applications should potentially be fast-tracked to avoid being deterred "by long wait times, complex application procedures, or restrictive visa conditions" (ibid.). As demonstrated by Borjas (2009a) however, such workers' actual rather than presumed labour market impacts merit review - particularly if protection of US workers is a primary policy value. To date there has been remarkably little global investigation of international students' rank in the "emerging global meritocracy" (Wildavesky, 2010; Haupt et al., 2011). In 2004 researchers were obliged 'to make do with incomplete data', with 'lack of information on change from the status of student to holder of a work permit or permanent immigrant status', and minimal measurement of any kind at the international level (Tremblay, 2004).

By 2013, this remained the case. A review of the global literature asserted there to be a compelling case for more adequate understanding of the study-migration phenomenon, including "...further research on (international student migration) and datasets and quantitative surveys, which employ statistical analysis; more attention to gender and race as they relate to ISM; and a stronger link to pedagogy and systems of higher education and knowledge production" (King and Rahguram, 2013) These issues are highly relevant to the US. According to the Science and Engineering Indicators 2016 report it currently retains for at least five years 66 per cent of temporary visa holders who have earned US science and engineering doctorates, in a context where "Foreign-trained doctorates in the field have grown 
significantly over time... (but) data on this segment of the workforce are limited" (National Science Board, 2016).

\subsubsection{Australia - the impact of oversupply on employment outcomes}

Australia has a capacity to address this issue - along with Canada operating the world's largest proactive skilled migration programme. In 2015-16 it admitted 190,000 permanent migrants (68 per cent skilled) in addition to 25,000 humanitarian entrants, with 174,900 temporary foreign workers also resident. In 2016 712,884 international students were also enrolled (half in the tertiary sector), with the potential to transit to permanent status (Knott, 2017). Skilled migrant outcomes thus represent a critical policy issue for Australia, in a context where the study-migration pathway was introduced from 1999. By 2006 international students had a 99 per cent chance of selection (unless failing health or character checks), with 66 per cent of Indian and 38 per cent of Chinese students category-switching to stay. That year however the most comprehensive skilled migration review in 20 years identified challenging policy issues. While the study-migration pathway could confer significant employment protection (most notably with 75 per cent of onshore Chinese employed at six months compared to 55 per cent selected offshore), growing numbers of international students had trained in low-grade private vocational courses, with compromised English and academic entry standards. While 83 per cent of former students were employed at 6 months (compared to 82 per cent of offshore skilled migrants), they secured annual salaries of $\$ A 33,000$ compared to $\$ A 52,500$. They had lower job satisfaction (44 per cent liking their work compared to 57 per cent of migrants selected offshore). They were also less likely to use their qualifications in work (46 per cent compared to 63 per cent) (Birrell et al., 2006; Hawthorne, 2014).

Australia collects the world's most comprehensive data on skilled migration. Given this, the third case study allows assessment of the extent to which international students are sought by host country employers relative to new domestic graduates, and to mature-age migrants selected offshore, including the most significant attributes. For this purpose three major datasets were examined.

\subsubsection{The scale of employer sponsorship of former international students}

The first question concerns the degree to which employers seek international students as temporary or permanent skilled workers, 10-15 years following Australia's establishment of the study-migration pathway. To examine this, analysis of all skilled migration entry visas was undertaken for a six-year period from June 2008 to 2014, by key variables including source country and field. As demonstrated by Table 10.4, 50 per cent of permanent skilled migrants and 51 per cent of temporary foreign workers were selected in Australia in this period (the great majority as former international students). Within the permanent programme, 70 per cent of accountants were selected onshore, compared to 58 per cent of nurses, 37 per cent of computing/IT workers, 35 per cent of engineers and 29 per cent of doctors (with mature experience in select fields clearly valued). Within the temporary 457 visa category (where migrants were admitted to work up to four years in under-supplied sectors or sites) onshore sponsorship rates ranged from 62 per cent of nurse approvals to 49 per cent of accountants, 40 per cent of engineers, 35 per cent of doctors and 22 per cent of computing/IT workers. In brief, Australian employers demonstrated a keen interest in the study-migration pathway. Their level of interest however was significantly influenced by occupational field.

\section{<Insert Table 10.4 here>}


The second question concerns the extent to which Australian employers value international students relative to mature skilled migrants selected offshore. The Department of Immigration and Border Protection's (DIBP) Continuous Survey of Australia's Migrants (CSAM) was examined in order to assess this. Introduced in 2009, six- and 12-month CSAM surveys are administered to a representative sample of newly-arrived permanent skilled migrants, with data in Table 10.5 derived from five cohorts arriving from 2009-11. Former international students' outcomes are summarised in the "Onshore Independent" and "Skilled Graduate" categories, noting that by definition all skilled migrants had been competitively screened for English ability, qualification level, and additional human capital attributes (Department of Immigration and Citizenship, 2012). As shown, 92 per cent of employer-sponsored migrants were fully employed at six months, of whom 90 per cent had skilled work (defined as professional or managerial positions). Offshore Independent migrants fared less well, with 72 per cent employed full-time, and of these 75 per cent using their skills. Results were significantly worse for former international students, despite exceptional labour market participation rates (98 per cent) and minuscule reported unemployment (3-6 per cent). Sixty-nine percent of Onshore Independent respondents were immediately working full-time, and 65 per cent of Skilled Graduates. Of these just over half were employed in skilled positions ( 55 per cent and 58 per cent respectively). While modest gains were evident at 12 months (77 per cent of Onshore Independent respondents employed full-time and 74 per cent of Skilled Graduates), only 61-62 per cent of these had professional or managerial positions. Serious wage differentials existed, with Sponsored migrants reporting median salaries of $\$ A 75,000$ at 12 months, compared to $\$ A 47,000$ for Onshore Independents and $\$ 41,600$ for Skilled Graduates. It is worth noting that such wages were at or below the norm for Family category migrants at this time $(\$ A 44,200)$, who had arrived unscreened in advance for human capital attributes. The workforce contribution of former international students has risen since. By 201458 per cent of skilled migrants held an Australian qualification (typically a degree), with six-month full-time skilled employment rates rising (Department of Immigration and Border Protection, 2014, 2016).

\section{<Insert Table 10.5 here>}

\subsubsection{Impact of sector demand on former international student employment rates relative to local graduates}

The third question concerns the extent to which former international students are sought relative to recent 'local' graduates (directly comparable new labour market entrants), in the context of variable labour market demand. It is important to note that international students are associated with highly skewed enrolment patterns and source countries in Australia (a pattern replicated globally). In terms of the tertiary sector, by 200543,036 were undertaking business and commerce degrees, compared to 20,681 in IT, 13,648 in accounting, 10,203 in engineering, and modest numbers in other fields. Chinese (41,812 degree enrolments), Indian (21,111) and Malaysian $(13,892)$ students dominated tertiary sector enrolments, compared to modest numbers of international students from the UK/Europe $(8,240)$, and North America (5,014). By 2009 Australian employers were reportedly being 'deluged' by international student applications in over-supplied fields. For example 7,751 international students sought accounting 
work in Australia in the five years to 2011, compared to just 2,852 Australian accounting graduates. A comparable pattern prevailed in IT (Hawthorne, 2010).

Within this context, Australia's Graduate Destination Survey data (GDS) were examined from 200711 , to assess international students' employment outcomes four months following course completion relative to new domestic graduates. Graduates were included if they had completed an Australian degree at the bachelor, masters or doctoral level, yielding 450,997 responses in all (79,046 international respondents compared to 371,951 local students). Eleven fields of qualification were analysed, associated with:

- Strong labour market demand (medicine, nursing, dentistry, pharmacy and physiotherapy);

- Significant oversupply (business and commerce, accounting and IT);

- Volatile demand (engineering); and

- Modest demand (education and the law) (Hawthorne and To, 2014) ${ }^{\mathrm{i}}$.

As demonstrated by Table 10.6, labour market demand by field profoundly influenced early employment outcomes. Four months after graduation, 51 per cent of former international student graduates with bachelor qualifications were employed full-time, compared to 81 per cent of Australian citizens/permanent residents. Outcomes however varied markedly across occupations. For example Australia imported around 95,000 migrant health professionals in the eight years to 30 June 2016, to address undersupply and maldistribution. In the context of strong health workforce demand, differences in outcome between domestic and international students were negligible. 98.8 per cent of former international medical students were fully employed (compared to 99.7 per cent of domestic graduates); in dentistry 95.5 per cent (compared to 93.5 per cent); and in pharmacy 96.1 per cent (compared to 97.6 per cent). These were exceptional rates compared to medical and allied health migrants selected across all immigration categories (for example with 57 per cent of medical migrants by 2011 employed as doctors within five years of arrival).

\section{<Insert Table 10.6 here>}

International students fared poorly, by contrast, in the over-supplied and volatile fields where employers markedly favoured domestic students:

- Engineering: 43.6 per cent of international students employed full-time (compared to 86.4 per cent of local graduates)

- Information technology: 42.3 per cent (compared to 78.0 per cent)

- Business and commerce: 39.7 per cent (compared to 76.4 per cent)

- Accounting: 35.2 per cent (compared to 82.7 per cent)

International students qualified with masters by coursework degrees did worse, given few such courses led to vocational registration with the exception of education and accounting. Just 39.5 per cent were fully employed at four months, compared to 87 per cent of domestic students - with demand once again powerfully influencing national outcomes. 


\subsubsection{Influence of international student characteristics on early employment outcomes}

The fourth question concerns the attributes Australian employers seek for knowledge economy work including the impact of English ability and visible minority status on preliminary employment outcomes. Analysis of the 2007-11 Graduate Destination Survey responses provides definitive insight concerning this, the analysis in this case aggregating all major fields. In terms of bachelor graduates, US/Canadian (76 per cent), Singaporean (56 per cent), Malaysian (55 per cent) and Indian (53 per cent) students were the most immediately sought after (by definition native English speakers, or fluent speakers from Commonwealth source countries). This compared to 49 per cent employment rates for all international students. Those from Sri Lanka (39 per cent), China (42 per cent), Indonesia (41 per cent) and Vietnam (43 per cent) fared worst, as did former international students seeking work in oversubscribed fields such as accounting, business and IT, where employers had become highly selective. Regression analysis demonstrated early full-time employment for bachelor graduates to be a function of main language background, discipline of qualification, and residential rather than visible minority status (Table 10.7).

International students for whom English was the main language background were 43 per cent more likely to be in full-time employment compared to their non-English background counterparts. Graduates with bachelor qualifications in the areas of medicine, dentistry and pharmacy were also 1.4 times more likely to be working full-time compared to those who had completed their degree in accounting, business and commerce or information technology (Hawthorne and To, 2014).

\section{<Insert Table 10.7 here>}

Comparable trends existed for former international students with master's degrees, where 37 per cent of international students had full-time employment across all fields, and those from Nepal (25 per cent), Vietnam (28 per cent), China ( 29 per cent) and Pakistan (31 per cent) were most disadvantaged. Outcomes were best for $\mathrm{PhD}$ qualified international students, where length and calibre of study could enhance their competitiveness (noting most doctoral courses mandated higher English and academic entry standards). Seventy-nine per cent of UK/Ireland and Canada/US international PhD graduates had reported full-time work at four months, compared to 77 per cent from Vietnam, 75 per cent from Malaysia, 74 per cent from Germany, 69 per cent from China and 67 per cent from India (Table 10.8).

\section{<Insert Table 10.8 here $>$}

Based on research findings such as these, the Australian government has fine-tuned the study-migration pathway from 2007 to 2017 - emphasising advanced English language ability, degree qualifications, occupational demand, work experience, and most notably direct employer sponsorship.

\section{4 Conclusion}

According to Wang (2013), there have been three waves of globalization to date. The first involved goods, the second involved financial services, and the third involves talent. Defining, attracting and retaining the 'best' talent however is complex, in an increasingly competitive global environment. As demonstrated by this chapter, former international students are now courted by a wide range of governments, as potential "designer immigrants" (Simmons, 1999). Much is claimed for their value as 
an adjunct workforce in waiting, including their potential to offer a productivity premium. International students are of prime workforce age. They have been self-funded to meet domestic workforce requirements. They should face less risk of skills discounting than migrants qualified overseas, given immediate credential recognition, acculturation, and host country language ability. At the same time policy formation has proven challenging in the context of competing national aims, and when informed by limited empirical data. As demonstrated by the UK case study, international students can inflate net migration flows and fuel populist debate - resulting in pathway cuts regardless of their prospective value as skilled migrants. As illustrated by the US and UK case studies, students' retention can lead to labour market substitution rather than complementarity - problematic if protection of local jobs is a primary policy aim. As shown by the Australian case study, employers demonstrate keen interest in the study-migration pathway but demand skilled workers with strong host country language ability, advanced qualifications and permanent resident status. In oversupplied fields they also show a marked preference for domestic graduates. These issues merit consideration by countries in the process of expanding the study-migration pathway. While national governments frame skilled migration policies, these require public acceptance. It is also employers who have the power to offer or withhold work. 


\section{Tables}

Table 10-1 International tertiary students by top twenty host countries (by national fertility rates)

\begin{tabular}{|c|c|c|c|c|c|}
\hline Host Country & 2005 & 2011 & $\begin{array}{c}2011 \% \text { of } \\
\text { Tertiary } \\
\text { enrolments }\end{array}$ & $\begin{array}{c}2011 \% \\
\text { From Asia }\end{array}$ & $\begin{array}{l}2014 \text { National } \\
\text { Fertility Rate }\end{array}$ \\
\hline United States & 590,200 & 709,600 & 3.4 & 71.7 & 2.06 \\
\hline United Kingdom & 318,410 & 419,900 & 16.8 & 51.9 & 1.90 \\
\hline China & 141,100 & 292,600 & 0.9 & 87.4 & 1.55 \\
\hline France & 236,500 & 268,200 & 11.9 & 21.8 & 1.94 \\
\hline Australia & 177,000 & 262,600 & 19.8 & 80.7 & 1.77 \\
\hline Germany & $* 177,800$ & 176,700 & 6.4 & 31.4 & 1.43 \\
\hline Japan & 125,900 & 151,500 & 3.9 & 93.3 & 1.40 \\
\hline Canada & 75,500 & 106,300 & 7.4 & 54.1 & 1.59 \\
\hline Singapore & 66,000 & 91,500 & N/A & N/A & 0.80 \\
\hline Malaysia & $* 44,400$ & 90,000 & N/A & N/A & 2.58 \\
\hline Italy & 44,900 & 73,500 & 3.7 & 22.8 & 1.42 \\
\hline Republic of Korea & 15,500 & 62,700 & 1.9 & 94.1 & 1.25 \\
\hline Spain & 17,700 & 62,600 & 3.2 & 4.4 & 1.48 \\
\hline Switzerland & $* 31,700$ & 41,800 & 16.2 & 10.5 & 1.48 \\
\hline New Zealand & 40,800 & 40,900 & 15.6 & 67.9 & 2.05 \\
\hline Netherlands & 26,400 & 38,400 & 4.9 & 15.9 & 1.78 \\
\hline Czech Republic & 18,500 & 38,000 & 8.5 & 9.8 & 1.30 \\
\hline Sweden & 18,900 & 36,500 & 7.9 & 46.0 & 1.67 \\
\hline Greece & 15,700 & 32,800 & 5.0 & 46.1 & 1.41 \\
\hline Turkey & 18,200 & 31,100 & 0.8 & 57.0 & 2.08 \\
\hline
\end{tabular}

Source: Adapted from OECD (2014) The International Mobility of Students and Its Links With Labor Migration, OECD, Paris, Table 2.1, p. 17. *German \& Swedish data for 2008, Malaysia data for 2006; Geoba (2014), 'World: Total Fertility rate (2014),

http://www.geoba.se/population.php?pc=world\&type=10\&year=2014\&st=rank\&asde=\&page=2, 18 October. 
Table 10-2 Grants of Extensions to Work in the UK: Tiers 1 and 22013 and 2014

\begin{tabular}{|l|l|l|l|l|}
\hline Category & $\begin{array}{l}\text { Year to } \\
\text { March 2013 }\end{array}$ & $\begin{array}{l}\text { Year to } \\
\text { March 2014 }\end{array}$ & $\begin{array}{l}\text { Change (Latest } \\
\mathbf{1 2} \text { Months) }\end{array}$ & $\begin{array}{l}\text { Change } \\
\text { Chang }\end{array}$ \\
\hline Total Tier 1 Pre-PBS Equivalent of which: & 77,079 & 32,210 & $-44,869$ & $-58 \%$ \\
\hline Tier 1 - Entrepreneurs & 1,907 & 6,684 & $+4,777$ & $-54 \%$ \\
\hline Tier 1 - General & 51,117 & 23,678 & $-27,439$ & $-97 \%$ \\
\hline Tier 1 - Post-Study & 23,149 & 713 & $-22,436$ & $+18 \%$ \\
\hline Total Tier 2 + Pre-PBS Equivalent of which: & 55,262 & 65,043 & $+9,781$ & $+27 \%$ \\
\hline Tier 2 - General & 35,795 & 45,507 & $+9,712$ & \\
\hline
\end{tabular}

Source: Adapted from Grants of Extensions: Tiers 1 and 2 Table (p. 40), UK Government (2014), Immigration Statistics, January to March 2014', https://www.gov.uk/government/publications/immigration-statistics-januaryto-march-2014, accessed 22 August 2014. 
Table 10-3 Five-Year Percentage Stay Rates for US Science and Engineering Doctorate Recipients With Temporary Visas at Graduation, by Select Country/ Region/ Economy (2001-

11)

\begin{tabular}{|c|c|c|c|c|c|c|}
\hline Student Country/ Region/ Economy & 2001 & 2003 & 2005 & 2007 & 2009 & 2011 \\
\hline Total & 58 & 64 & 67 & 63 & 62 & 66 \\
\hline China & 98 & 93 & 95 & 94 & 89 & 85 \\
\hline India & 89 & 90 & 89 & 83 & 79 & 82 \\
\hline Europe & 53 & 63 & 67 & 67 & 60 & 62 \\
\hline Canada & 66 & 63 & 60 & 56 & 53 & 55 \\
\hline South Korea & 22 & 36 & 44 & 42 & 42 & 42 \\
\hline Japan & 24 & 39 & 41 & 33 & 40 & 38 \\
\hline Taiwan & 41 & 48 & 52 & 43 & 37 & 38 \\
\hline Mexico & 31 & 22 & 32 & 33 & 35 & 39 \\
\hline Brazil & 26 & 26 & 31 & 32 & 33 & 37 \\
\hline
\end{tabular}

Source: M. Finn (2014), Stay Rates of Foreign Doctoral Recipients from US Universities: 2011, Oak Ridge Institute for Science and Education, Oak Ridge, presented as Table 3-29 in Science and Engineering Indicators 2014, National Science Foundation, Washington DC, p. 3-57. 
Table 10-4 Australian Employer Demand for Skilled Migrants, Temporary Compared to Permanent Categories, by Major Field and Selection Location (30 June 2008 to 30 June 2014)

\begin{tabular}{|c|c|c|c|c|c|c|c|}
\hline $\begin{array}{l}\text { Skilled Migration } \\
\text { Category }\end{array}$ & 2008-09 & 2009-10 & 2010-11 & 2011-12 & 2012-13 & 2013-14 & $\begin{array}{l}\text { \% Selected } \\
\text { Onshore 2013-14 }\end{array}$ \\
\hline \multicolumn{7}{|c|}{ Temporary Stock: Resident (457 Visa) } & $\begin{array}{l}\text { \% New 2013-14 } \\
\text { Approvals Only }\end{array}$ \\
\hline Computing/ IT & 7,150 & 7,360 & 9,010 & 10,490 & 11,050 & 10,880 & $22.2 \%$ \\
\hline Engineering & 6,670 & 5,620 & 6,210 & 8,280 & 8,070 & 6,160 & $39.8 \%$ \\
\hline Accounting & 2,580 & 2,470 & 2,710 & 3,330 & 3,840 & 4,010 & $48.9 \%$ \\
\hline Nursing & 4,560 & 3.850 & 3,300 & 4,070 & 4,770 & 3,810 & $61.6 \%$ \\
\hline Medicine & 5,060 & 4,600 & 4,990 & 5,030 & 4,590 & 4,160 & $34.7 \%$ \\
\hline Education & 1,220 & 1,130 & 1,420 & 2,190 & 2,830 & 2,910 & $50.8 \%$ \\
\hline Total (all fields) & 77,300 & 68,400 & 72,030 & 91,050 & 107,970 & 108,870 & $50.9 \%$ \\
\hline \multicolumn{7}{|c|}{ Permanent Arrivals: (GSM Visa) } & $\begin{array}{l}\%+\text { Total 2008-14 } \\
\text { Approvals }\end{array}$ \\
\hline Computing/ IT & 4,774 & 5,205 & 4,468 & 8,538 & 8,389 & 7,975 & $37.2(39,349)$ \\
\hline Engineering & 4,319 & 5,907 & 4,112 & 4,891 & 3,898 & 4,160 & $35.2(27,287)$ \\
\hline Accounting & 6,642 & 6,783 & 14,949 & 7,303 & 6,022 & 6,880 & $70.1(48,579)$ \\
\hline Nursing & 1,357 & 1,700 & 1,374 & 1,174 & 1,404 & 2,761 & $57.5(9,770)$ \\
\hline Medicine & 446 & 1,070 & 508 & 1,037 & 1,289 & 1,134 & $28.8 \%(5,484)$ \\
\hline Education & 883 & 754 & 467 & 730 & 912 & 961 & $37.5(4,707)$ \\
\hline Total (all fields) & 33,604 & 28,042 & 34,913 & 36,893 & 39,147 & 38,130 & $50.0(210,729)$ \\
\hline
\end{tabular}

Source: Adapted from unpublished Department of Immigration and Border Control immigration arrivals data for permanent compared to temporary skilled migration categories, provided to L Hawthorne August 2014. 
Table 10-5 Australian Employment Outcomes (at 6 months), by Skilled Migration SubCategory (2009-11)

\begin{tabular}{|l|l|l|l|l|l|l|}
\hline $\begin{array}{l}\text { Visa Reporting } \\
\text { Category }\end{array}$ & $\begin{array}{l}\text { Skilled } \\
\text { Job }\end{array}$ & $\begin{array}{l}\text { Other } \\
\text { Job }\end{array}$ & $\begin{array}{l}\text { Not } \\
\text { Working }\end{array}$ & $\begin{array}{l}\text { Working } \\
\text { Full-time }\end{array}$ & $\begin{array}{l}\text { Participation } \\
\text { Rate }\end{array}$ & $\begin{array}{l}\text { Median } \\
\text { Full-time } \\
\text { Earnings }\end{array}$ \\
\hline Employer Sponsored & 90 & 7 & 3 & 92 & 98 & $\$ 71,300$ \\
\hline Family/State Sponsored & 60 & 31 & 9 & 72 & 98 & $\$ 50,000$ \\
\hline Offshore Independent & 75 & 12 & 12 & 76 & 97 & $\$ 74,600$ \\
\hline Onshore Independent & $\mathbf{5 5}$ & $\mathbf{3 7}$ & $\mathbf{8}$ & $\mathbf{6 9}$ & $\mathbf{9 8}$ & $\mathbf{\$ 4 4 , 4 0 0}$ \\
\hline Skilled Graduates & $\mathbf{5 8}$ & $\mathbf{3 6}$ & $\mathbf{5}$ & $\mathbf{6 5}$ & $\mathbf{9 8}$ & $\mathbf{\$ 4 0 , 0 0 0}$ \\
\hline Other Skilled & 47 & 33 & 20 & 61 & 86 & $\$ 43,000$ \\
\hline All Skilled & 68 & 24 & 8 & 75 & 96 & $\$ 52,000$ \\
\hline
\end{tabular}

Source: Adapted from Department of Immigration and Citizenship Continuous Survey on Australian Migration longitudinal data. 
Table 10-6 Impact of Demand by Field on International Student Employment Outcomes Relative to Domestic Student Graduates with Bachelor Degrees (Graduate Destination Survey 2009 to 2011)

\begin{tabular}{|c|c|c|c|c|c|c|c|c|c|}
\hline \multirow[b]{2}{*}{ Activity } & \multicolumn{4}{|c|}{ Domestic Students } & \multicolumn{4}{|c|}{ International Students } & \multirow{2}{*}{$\begin{array}{l}\text { Total } \\
2009- \\
2011\end{array}$} \\
\hline & 2009 & 2010 & 2011 & Total & 2009 & 2010 & 2011 & Total & \\
\hline \multicolumn{10}{|l|}{ Medicine } \\
\hline Working FT (\%) & 99.5 & 99.8 & 99.7 & 99.7 & 96.9 & 98.8 & 100 & 98.8 & 99.6 \\
\hline Available for FT work (N) & 744 & 842 & 1144 & 2730 & 98 & 165 & 161 & 424 & 3154 \\
\hline \multicolumn{10}{|l|}{ Pharmacy } \\
\hline Working FT (\%) & 97.9 & 97.4 & 97.5 & 97.6 & 98.3 & 96.6 & 93.1 & 96.1 & 97.3 \\
\hline Available for FT work (N) & 481 & 538 & 484 & 1503 & 116 & 89 & 102 & 307 & 1810 \\
\hline \multicolumn{10}{|l|}{ Accounting } \\
\hline Working FT (\%) & 86.3 & 80.9 & 81.1 & 82.7 & 41.7 & 32.9 & 31.6 & 35.2 & 69.6 \\
\hline Available for FT work $(\mathrm{N})$ & 3213 & 3233 & 3373 & 9819 & 1193 & 1211 & 1340 & 3744 & 13563 \\
\hline \multicolumn{10}{|l|}{ Business / Commerce } \\
\hline Working FT (\%) & 77.2 & 75.6 & 76.4 & 76.4 & 39.4 & 39.4 & 40.3 & 39.7 & 72.9 \\
\hline Available for FT work (N) & 6282 & 6665 & 7035 & 19982 & 672 & 649 & 780 & 2101 & 22083 \\
\hline \multicolumn{10}{|l|}{ Information Technology } \\
\hline Working FT (\%) & 79.9 & 74.8 & 79.1 & 78.0 & 43.3 & 43.5 & 40.1 & 42.3 & 71.2 \\
\hline Available for FT work (N) & 1704 & 1566 & 1592 & 4862 & 397 & 347 & 394 & 1138 & 6000 \\
\hline \multicolumn{10}{|l|}{ Engineering } \\
\hline Working FT (\%) & 88.3 & 84 & 86.7 & 86.4 & 51.1 & 39.5 & 40.5 & 43.6 & 80.8 \\
\hline Available for FT work (N) & 2708 & 2455 & 2652 & 7815 & 372 & 334 & 467 & 1173 & 8988 \\
\hline \multicolumn{10}{|l|}{ All Disciplines } \\
\hline Working FT (\%) & 79.3 & 76.6 & 76.8 & 77.5 & 50.9 & 46.4 & 43.2 & 46.7 & 46.7 \\
\hline Available for FT work (N) & 39174 & 39448 & 41506 & 120128 & \begin{tabular}{l|l}
3 & 4194
\end{tabular} & 4268 & 4675 & 13137 & 13137 \\
\hline
\end{tabular}

Source: Hawthorne, L \& To, A (2014), 'Employer Response to the Study-Migration Pathway: The Australian Evidence 2007-2011', Highly Skilled Migration: Policies, Processes and Politics, Special Issue, International Migration, 52(3). 
Table 10-7 Logistic Regression of Potential Predictors of Full-time Work Outcomes, Year after Course Completion (2007-2011)

\begin{tabular}{|l|l|l|c|c|c|}
\hline Predictor & Base & Comparator & $\begin{array}{c}\text { Significa } \\
\text { nce } \\
\text { (p-level) }\end{array}$ & $\begin{array}{c}\text { Odds } \\
\text { Ratio }\end{array}$ & 95\% CI \\
\hline $\begin{array}{l}\text { Permanent } \\
\text { residency }\end{array}$ & $\begin{array}{l}\text { Australian residency or } \\
\text { citizenship }\end{array}$ & $\begin{array}{l}\text { Overseas permanent } \\
\text { residency }\end{array}$ & 0.003 & 0.651 & $0.493-$ \\
\hline $\begin{array}{l}\text { Language } \\
\text { background }\end{array}$ & English & Other language & 0.000 & 0.550 & $0.414-$ \\
\hline Region of origin & $\begin{array}{l}\text { English speaking } \\
\text { background country }\end{array}$ & All other countries & 0.213 & 0.732 & $0.449-$ \\
\hline $\begin{array}{l}\text { Level of } \\
\text { qualification }\end{array}$ & Bachelor degree & Masters degree & 0.000 & 3.318 & $1.726-$ \\
& & & & & 6.376 \\
\cline { 2 - 6 } & & Doctorate & 0.000 & 3.660 & $1.908-$ \\
\hline Discipline & Accounting or Business and & Health & & & 7.021 \\
\hline & Commerce & All other disciplines & 0.000 & 0.274 & $0.176-$ \\
& & & & & 0.426 \\
\hline
\end{tabular}

Source: Hawthorne, L \& To, A (2014), 'Employer Response to the Study-Migration Pathway: The Australian Evidence 2007-2011', Highly Skilled Migration: Policies, Processes and Politics, Special Issue, International Migration, 52(3). 
Table 10-8 Full-time Employment Outcomes at Four Months for International Student Graduates by Top Ten Countries of Permanent Residence and Course Level for All Disciplines, Graduate Destination Survey 2007 to 2011

\begin{tabular}{|c|c|c|c|c|c|c|}
\hline \multirow[b]{2}{*}{ Course Level } & \multirow[b]{2}{*}{$\begin{array}{l}\text { Country of Permanent } \\
\text { Residence }\end{array}$} & \multicolumn{5}{|c|}{ Activity } \\
\hline & & $\begin{array}{r}\text { Work } \\
\text { FT }\end{array}$ & $\begin{array}{r}\text { Not in FT } \\
\text { work * }\end{array}$ & $\begin{array}{r}\text { Work } \\
\text { FT }\end{array}$ & $\begin{array}{r}\text { Not in FT } \\
\text { work * }\end{array}$ & Total \\
\hline \multirow{12}{*}{$\begin{array}{l}\text { National Total (All } \\
\text { Course Levels) }\end{array}$} & China & $36 \%$ & $64 \%$ & 3301 & 5786 & 9087 \\
\hline & India & $47 \%$ & $53 \%$ & 3049 & 3477 & 6526 \\
\hline & Malaysia & $54 \%$ & $46 \%$ & 1581 & 1346 & 2927 \\
\hline & Indonesia & $40 \%$ & $60 \%$ & 629 & 930 & 1559 \\
\hline & Hong Kong & $43 \%$ & $57 \%$ & 628 & 845 & 1473 \\
\hline & Singapore & $55 \%$ & $45 \%$ & 590 & 488 & 1078 \\
\hline & Sri Lanka & $39 \%$ & $61 \%$ & 309 & 490 & 799 \\
\hline & Canada/USA & $74 \%$ & $26 \%$ & 588 & 210 & 798 \\
\hline & Nepal & $31 \%$ & $69 \%$ & 221 & 489 & 710 \\
\hline & Korea (South) & $47 \%$ & $54 \%$ & 324 & 373 & 697 \\
\hline & All Other & $51 \%$ & $49 \%$ & 4194 & 4019 & 8213 \\
\hline & Total & $46 \%$ & $55 \%$ & 15414 & 18453 & 33867 \\
\hline \multirow{12}{*}{$\begin{array}{l}\text { Doctorate - National } \\
\text { Total }\end{array}$} & China & $69 \%$ & $31 \%$ & 98 & 44 & 142 \\
\hline & India & $67 \%$ & $33 \%$ & 59 & 29 & 88 \\
\hline & Canada/USA & $79 \%$ & $22 \%$ & 51 & 14 & 65 \\
\hline & Germany & $74 \%$ & $26 \%$ & 39 & 14 & 53 \\
\hline & Malaysia & $75 \%$ & $26 \%$ & 35 & 12 & 47 \\
\hline & Iran & $66 \%$ & $34 \%$ & 29 & 15 & 44 \\
\hline & Viet Nam & $77 \%$ & $23 \%$ & 33 & 10 & 43 \\
\hline & UK/Ireland & $79 \%$ & $21 \%$ & 30 & 8 & 38 \\
\hline & Bangladesh & $60 \%$ & $41 \%$ & 22 & 15 & 37 \\
\hline & Singapore & $76 \%$ & $24 \%$ & 25 & 8 & 33 \\
\hline & All Other & $73 \%$ & $27 \%$ & 282 & 102 & 384 \\
\hline & Total & $72 \%$ & $28 \%$ & 703 & 271 & 974 \\
\hline
\end{tabular}

Source: Hawthorne, L \& To, A (2014), 'Employer Response to the Study-Migration Pathway: The Australian Evidence 2007-2011', Highly Skilled Migration: Policies, Processes and Politics, Special Issue, International Migration, 52(3). 


\section{References}

AFP The Times (2014) Britain to Ban Migrant Welfare. Syndicated in The Weekend Australian, Sydney, 29 November.

Australian Education International (2016) International Student Enrolment Data. Available from: https://internationaleducation.gov.au/research/International-Student-

Data/PublishingImages/IST_2016/2016Graph_Table1.png [Accessed 29 June 2016].

Asian Development Bank (2006) Converting Migration Drains Into Gains: Harnessing the Resources of Overseas Professionals, Wescott, C. \& Brinkerhoff, J. (Eds.) ADB, Manila.

Belkhodja, C. (2011) Introduction. International Migration: The Emergence of the Mobile Student. Canadian Diversity. 8 (5).

Benton, M., Sumption, M., Alsvik, K., Fratzke, S., Kuptsch, C. \& Papademetriou, D. (2014) Aiming Higher: Policies to Get Immigrants Into Middle-Skilled Work in Europe. Washington, D.C.: Migration Policy Institute, p. 1.

Birrell, B., Hawthorne, L. \& Richardson, S. (2006) Review of the General Skilled Migration Program, Commonwealth of Australia, Canberra. Available from: http://www.immi.gov.au/media/publications/research/gsm-report/index.htm

Blinder, S. (2015) Briefing: UK Public Opinion toward Immigration: Overall Attitudes and Level of Concern. The Migration Observatory, University of Oxford.

Blinder (2016) Briefing: Immigration by Category: Workers, Students, Family Members, Asylum Applicants. The Migration Observatory, University of Oxford.

Borjas, G. J. (2009a) Immigration in High-Skill Labor Markets: The Impact of Foreign Students on the Earnings of Doctorates. In: Freeman, R. B. \& Goroff, D. L. (eds.) Science and Engineering Careers in the United States: An Analysis of Markets and Employment. Chicago: University of Chicago Press.

Borjas, G. J. (2009b) Recent Trends in the Earnings of New Immigrants to the United States. NBER Working Paper 15406, National Bureau of Economic Research, Cambridge MA.

Borjas, G. J., Grogger, J. \& Hanson, G. H. (2011) Substitution between Immigrants, Natives, and Skills Groups. NBER Working Paper 17461, National Bureau of Economic Research, Cambridge MA.

Borjas, G. J. \& Doran, K. B. (2012) The Collapse of the Soviet Union and the Productivity of American Mathematicians. NBER Working Paper 17800, National Bureau of Economic Research, Cambridge MA.

Card, D. (2009) Immigration and Inequality. American Economic Review. 99.

Chia, S. (2011) Free Flow of Skilled Labor in the AEC. In: Urata, S. \& Okabe, M. (eds.) Towards a Competitive ASEAN Single Market: Sectoral Analysis. ERIA Research Project Report 2010-03, ERIA, Jakarta, p. 225.

Choudaha, R. \& Chang, L. (2012) Trends in International Student Mobility. Research Report 01, World Education Services, US.

Department of Homeland Security (2014), 'DHS Announces Proposals to Attract and Retain Highly Skilled Immigrants'. DHS Press Office, Release Date May 6.

Department of Immigration and Citizenship (2012) The Continuous Survey of Australia's Migrants: Cohorts 1 to 5 Report 2009-11. Canberra. 
Department of Immigration and Border Protection (2014) Continuous Survey of Australia's Migrants: Cohort 1 Report August 2014. Australian Government, Canberra.

Department of Immigration and Border Protection (2016) Continuous Survey of Australia's Migrants: Cohort 2 Report - Changes in Outcomes 2015. Australian Government, Canberra.

Devlin, C., Bolt, O., Patel, D., Harding, D. \& Hussain, I. (2014) Impacts of Migration on UK Native Employment: An Analytical Review of the Evidence. Home Office and Department for Business Innovation and Skills, Occasional Paper 109, March, London.

Doughty, S. (2007) Another Two Million Migrants in Ten Years. Daily Mail. 28 September.

Finn, F. (2014) Stay Rates of Foreign Doctoral Recipients from US Universities: 2011, Oak Ridge Institute for Science and Education, Oak Ridge.

Freeman, R., Stephan, P. \& Trumpbour, J. (2008) Career Patterns of Foreign Born Scientists and Engineerins Trained and or Working in the US. Workshop Report, National Bureau of Economic Research, Cambridge, MA.

Geoba (2014) World: Total Fertility rate (2014) Available from: http://www.geoba.se/population.php?pc=world\&type=10\&year=2014\&st=rank\&asde=\&page=2

[Accessed 18 October 2015].

Green, A. (2007) The Rising Wave That We Were Too Afraid to Discuss. Daily Telegraph. 24 October.

Gov.UK (2014) Immigration Statistics, January to March 2014. Available from: www.gov.uk/government/publications/immigration-statistics-january-to-march [Accessed 22 August 2014].

Hagen-Zanker, J. (2008) Who Do People Migrate? A Review of the Theoretical Literature'. In: Massey, D. S., Arango, J., Hugo, G., Kouaouci, A., Pellegrino, A. \& Taylor, J. E. (1993) Theories of International Migration: A Review and Appraisal. p. 12.

Haupt, A., Krieger, T. \& Lange, T ( 2011) Competition for the International Pool of Talent: Education Policy and Student Mobility. CESifo Working Paper, No 3421. Available from: http://www.cesifogroup.de/portal/pls/portal/docs/1/1200243.PDF [Accessed 26 September 2013].

Hawthorne, L. (2008) The Impact of Economic Selection Policy on Labour Market Outcomes for Degree-Qualified Migrants in Canada and Australia. Institute for Research on Public Policy, 14 (5), Ottawa.

Hawthorne, L. (2010) Demography, Migration and Demand for International Students. In: Findlay, C. \& Tierney, W. (eds.) Globalization and Tertiary Education in the Asia-Pacific - The Changing Nature of a Dynamic Market. Singapore: World Scientific Press, p. 101.

Hawthorne, L. (2014) Indian Students and the Evolution of the Study-Migration Pathway in Australia. International Migration. 52 (2), 3-19, April.

Hawthorne, L. \& To, A. (2014) Employer Response to the Study-Migration Pathway: The Australian Evidence 2007-2011. Highly Skilled Migration: Policies, Processes and Politics, Special Issue, International Migration. 52 (3), 99-115, August.

Higher Education Funding Council for England (2014) Global Demand for English Higher Education, April, HEFCE, London.

Home Office (2007) Accession Monitoring Report May 2004-September 2007 - A8 Countries, Border and Immigration Agency, Crown Copyright. 
House of Commons Library (2016) Migration Statistics. Briefing Paper Number SN06077, 26 May, London.

Hordern, B. ( 2012) US Fails to Link International Students with Immigration, Says IIE (International Education Institute). University World News, Available from: http://www.universityworldnews/com/article.php?story $=20120602082117310 \&$ mode $=[$ Accessed 4 June 2012].

International Organization for Migration (2003) The Migration-Development Nexus. Van Hear, N. \& Nyberg Sorensen, N. (eds.) Geneva.

Institute of International Education (2016) International Students in the United States. Available from: http://www.iie.org/Services/Project-Atlas/United-States/International-Students-In-

US\#.V3HVeE2e2JA [Accessed 28 June 2016].

King, R. \& Rahguram, P. (2013) International Student Migration - Mapping the Field and New Research Agendas. Population, Space and Place. 19.

Knott, M. (2017) A ‘Gangbuster’ Year for Foreign Students. The Age, 22 February, Melbourne.

Laczko, F. (2010) The Future of Migration Policies in the Asia-Pacific Region, Background Paper WMR 2010, International Organization for Migration, Geneva, Foreword.

Lee, P. (2014) New Visa Rules Will Help Attract and Retain Scholars. University World News. Available from: http://www.universityworldnews.com/article.php?story=20140508114945944 [Accessed 20 October 2014].

Marginson, S. (2010) Higher Education in East Asia and Singapore: Rise of the Confucian Model. International Journal of Higher Education Research. 61 (5).

Martin, P. \& Ruhs, M. (2010) Labour Shortages and US Immigration Reform: Promises and Perils of an Independent Commission. Centre on Migration, Policy and Society, Working Paper No. 81. Oxford: University of Oxford.

Mayer, M., Yamamura, S., Schneider, J. \& Muler, A. (2012) Immigration of International Students from Third Countries, Study for the German National Contact Point for the European Migration network, Federal Office for Migration and Refugees and European Migration Network, Working Paper 47, Germany, pp. 4, 25.

MacGregor, K. (2012) National Policies 'Massively' Influence Mobile Student Decisions. University World News Global Edition, Issue 224, 3 June, Available from: www.universityworldnews.com/article.php?story $=2012$

Migration Advisory Council (2012) Limits on Migration: Limit on Tier 2 (general) for 2012/13 and Associated Policies, London.

Migration Observatory (2011) Top Ten Problems in the Evidence Base for Public Debate and PolicyMaking on Immigration in the UK. Migration Observatory Report. 5 April, Oxford: University of Oxford.

Migration Observatory (2014a) Highly Skilled Migration to the UK. Migration Observatory Report. 3 July, Oxford: University of Oxford, Appendix.

Migration Observatory (2014b) Report: Highly Skilled Migration to the UK 2007-2013: Policy Changes, Financial Crises and a Possible "Balloon Effect". 3 July, Oxford: University of Oxford.

Musumba, M., Yanhong, H. J. \& Mjelde, J. (2011) Factors Influencing Career Location Preferences of International Graduate Students in the United States. Education Economics. 19 (5), December. 
National Science Foundation (2014) Science and Engineering Indicators 2014. Washington, D.C.

National Science Board (2016) Science and Engineering Indicators 2016. Washington, D.C.

OECD (2012) Immigration Outlook 2012, SOPEMI Report. Paris: OECD.

OECD (2014) The International Mobility of Students and Its Links With Labor Migration. Paris: OECD, p. 37.

Office of National Statistics (2014) Quality of Long-Term International Migration Estimates, 2001-11. ONS Migration Statistics Quarterly Report, London.

Office of National Statistics (2016) Quality of Long-Term International Migration Estimates 2 Series (LTIM Calendar Year). ONS Migration Statistics Quarterly Report, London.

Papademetriou, D. \& Sumption, M. (2013) Attracting and Selecting from the Global Talent Pool Policy Challenges. Washington, D.C: Migration Policy Institute.

Picot, G., Feng, H., \& Coulombe, S. (2007) Chronic Low-Income and Low-Income Dynamics among Recent Immigrants. Analytical Studies Research Papers, Statistics Canada Research Paper Series, Catalogue No. 11F0019MIE, No 294. Ottawa.

Ruhs, M. (2003) Temporary Foreign Worker Programmes: Policies, Adverse Consequences, and the Need to Make Them Work. Perspectives on Labour Migration 6, International Migration Branch, International Labour Office, Geneva.

Ruhs, M. (2014) The Price of Rights - Regulating International Labour Migration. New Jersey: Princeton University Press.

Sakur, S. (2016) Could British Voters Have Kickstarted the Unravelling of the EU? Hard Talk, BBC Radio, 30 June, Available from: http://www.bbc.co.uk/programmes/p004t1s0/episodes/player

Salt, J. (2011) International Students and the Labour Market. In: Madood, T. \& Salt, J. (eds.) Global Migration, Ethnicity and Britishness. London: Palgrave MacMillan.

Salt, J. \& Millar, J. (2006) Foreign Labour in the United Kingdom: Current Patterns and Trends. London: Office for National Statistics.

Sharma, Y. (2016) Brexit Vote Brings Uncertainty for British Universities. University World News, 27 June, Available from: http:///www.universityworldnews.com/article.php?story=20160624145955850

Shun, O. (2012) Southeast Asian Nurses and Caregiving Workers Transcending the National Boundaries: An Overview of Indonesian and Filipino Workers in Japan and Abroad. Southeast Asian Studies. 49 (4), March.

Simmons, A. (1999) International Migration and Designer Immigrants: Canadian Policy in the 1990s. In: Castro, M. (ed.) Free markets, open societies, closed borders? Trends in international migration and immigration policy in the Americas. Miami: North-South Center Press.

Simmons, J. (2014) Data provided to the author on UK Skilled Migration Policy, UK Home Office, 11 September.

Somerville, W. (2015) Assessing the Political Impact of Immigration as the United Kingdom Heads to the Polls. Migration Policy Institute. Available at: http://migrationpolicy.org/print/15253 [Accessed 10 April 2015]. 
Somerville, W. (2016) Brexit: The Role of Migration in the Upcoming EU Referendum. Migration Information Source, Migration Policy Institute, May 4. Available at: http://www.migrationpolicy.org/print/15626

Sumption, M. \& Bergeron, C. (2013) Remaking the US Green Card System. Issue Brief No. 6. Washington, D.C.: Migration Policy Institute.

Travis, A. (2011) Ministers Fail to Agree on How to Cut Number of International Students. Guardian, 4 March. Available at: http://www.guardian.co.uk/education/2011/mar/03/ministers-limitinternational-students [Accessed 24 May 2012], p.1.

Tremblay, K. (2004) Links between Academic Mobility and Immigration. Paper presented at the Symposium on International Labour and Academic Mobility: Emerging Trends and Implications for Public Policy, Toronto. Available from: http://www.wes.org/ewenr/symp/KarineTremblayPaper.pdf

UK Council for International Student Affairs (2016) International Student Statistics - UK Higher Education. Available from: http://institutions.ukcisa.org.uk//info-for-universities-colleges-schools/policy-research--statistics/research--statistics/international-students-in-uk-he/\#International(non-UK)-students-in-UK-HE-in-2014-15 [Accessed 29 June 2016].

United Nations (2013) International Migration Policies: Government Views and Priorities, Economic and Social Affairs, United Nations.

Vargas-Silva, C. (2013) Briefing: Migration Flows of A8 and Other EU Migrants To and From the UK. Migration Observatory, 17 January. Oxford: University of Oxford.

Vertovec, S. (2002) Transnational Networks and Skilled Labour Migration. Centre on Migration, Policy and Society, Working Paper. Oxford: University of Oxford, p. 13.

Vertovec, S. (2004), 'Trends and Impacts of Transnationalism', Centre of Migration, Policy and Society, Working Paper No. 3. Oxford: University of Oxford, p. 5.

Wang, H. (2013) Presentation on the Study-Migration Pathway, Metropolis International Conference, 11 September, Tampere.

Wildavesky, B. (2010) The Great Brain Race - How Global Universities Are Re-Shaping the World. New Jersey: Princeton University Press.

\footnotetext{
${ }^{\mathrm{i}}$ To define the scale of labour market demand relative to these, wide-ranging sources of information were used. These included decade trends in tertiary application rates, Australian Bureau of Statistics Labour Force Survey statistics, field-specific reviews, occupations defined as in shortage in Australia (e.g. on the Skilled Occupation List), and the scale of skilled migration by field.
} 